\title{
Alan Cawson
}

Those with a serious interest in politics and markets and in government-industry relations sooner or later confront the need to treat the firm as a collective political actor. Neither the political science literature on interest groups, nor the treatment of the firm in economic theory, is of much help. The first assumes that politics is confined to specialised associations; the second omits the political dimension altogether. There is a body of writing which links firm structure to other variables - the so-called 'structure-conduct-performance' paradigm [Mason 1957; Bain 1956] - but it too fails to consider politics, and imputes determinants of firm structure to factors such as concentration, barriers to entry, excess demand, and so on. The internal organisation of the firm, and the role of government, are ignored.

Two exceptions to this deserve a brief mention, and one merits particular attention. First, organisation theorists have developed models of the internal structure of firms which recognise a variety of interests, and the possibility of conflict over objectives and strategy [March 1962]. Second, in the wake of Chandler's pioneering analysis of the effect on firm structure of strategic adaptation to its environment [Chandler 1962], Channon has examined the development of multidivisional structures in British firms, linking this to changes in the nature of the market, which has become more international and more competitive [Channon 1973]. These writings suggest that in order to explore the role of firms as collective political and economic actors, we should: (i) study the organisation of firms, paying particular attention to how relations with government are handled, and how the organisation has changed in response to changes in public policy, and vice versa; and (ii) study the relationship between organisation and firm strategies. By strategies I mean more than simply objectives. Strategic action is the function of analysing market trends, technological developments and the actions of governments, and of devising a set of criteria derived from this analysis against which decisions can be taken. A firm which merely responds

\footnotetext{
' This article is extracted from a longer paper, 'Hostile Brothers: The Role of Firms in the Politics of Industry Sectors'. It draws on research into government-industry relations in the consumer electronics and telecommunications sectors in Britain, France and West Germany supported by the Economic and Social Research Council.
}

to developments as they occur has no strategy. A firm which attempts to build long-term considerations into short-term decisions is acting strategically [Ansoff 1968].

Strategic responses to changes in the market or in governmental policies can be constrained in various ways, and such constraints will vary considerably between countries. One important constraint in Britain is the short-term and conservative attitude of financial institutions, which are reluctant to provide 'patient money' where risk is assessed in terms of long-term prospects rather than short-term returns. In the electronics and telecommunications fields in the last two years we have seen two important examples of this. At STC (Standard Telephone and Cable), Sir Kenneth Corfield's ambitious attempt to restructure the firm around an Information Technology strategy was killed by a boardroom coup in which Corfield was sacked and replaced by a City trouble-shooter who could be counted on to make short-term returns a priority. At Thorn-EMI the attempt by Peter Laister to diversify into aerospace and semi-conductors through the bid for British Aerospace and the acquisition of Inmos dented City confidence, the share price took a dive, and he was replaced. (I make no claim that these strategies were likely to be successful, but use them as examples of the difficulty of planning for the long term in an environment dominated by financial institutions of the British kind. The point is that they were killed off before they could be put to the test.) The general point is that financial performance over a single year, if not six months, is critical in Britain if investor confidence is to be maintained, and this effectively means pleasing the major investing institutions, such as insurance companies and pension funds, if only in the short run. Any strategy which seeks to break free of these constraints is doubly risky.

Firm strategies may be developed in isolation, or through complementary strategies and alliances with other firms. In a market with a few large firms, each one will study the others closely, and each will take a close interest in the activities of governments (and of opposition parties in the approach to an election). This much is fairly straightforward. What is also interesting is the very different extent to which national governments take an interest in, and exert a direct influence over, firm strategies, especially with 
respect to international competition. Japan is commonly cited as the "ideal type' of this in the way that the Ministry of International Tride and Industry (MITI) used its control of technology imports in the 1950s to push particular firms into specific desired directions. Now MITI sponsors a forccistingplanning process in which "visions" of long-term trends are shilred with miljor firms. Many Europeans and Americins believe that MITl has organised the targeting of specific sectors by particular firms. those in a favoured "club" which excludes smaller producers. so that firm strategies are effectively coordinated by the stalte. Interestingly. the suspicion arises at the present timc. not least in the minds of Japanese managers intervicwed in the course of our present research, that the Korean government may now be doing just that in that its two biggest electronics firms, Silmsung and Goldstar. do not compete against each other in Western Europe or the United Stiltes, but appear to have divided the spheres between them.

Short of this kind of striltegic coordinition. assuming that it actually does hatppen in this wily. the policy priorities of governments can still affect the strategic calculations of firms. In Britain. governments have given significant priority to defence in their public spending decisions. so that major firms such as GEC and Racal build their strategies very profitably around defence contracting. The recognition of new areas for priority attention tends in Britain to lag behind what leading firms are already doing. Programmes such as the Microelectronics Applications Programme which is intended to encourage the application of microelectronics to manufacturing processes. are primarily mechanisms to prod laggards into adopting current best practice. It is an important role for government to speed the diffusion of innovations. but it hardly matches the extent to which the Japanese government is involved in the process of innovation itself. Where this does happen in Britain it is in the defence sector. and then the government is less active in finding civilian applications with potential mass consumer markets.

An alternative to government action in promoting innovation is action collectivcly by firms through their trade associations. It is clear from our research on government-industry relations that in our chosen sectors of telecommunications and consumer electronics this docs not happen at all. even in West Germany where there is strong evidence from the chemicals sectors [Grant. Paterson and Whitson 1985] that research is a major activity of the trade association - so much so that it is argucd to form a distinctive 'policy community'. In Britain the consumer electronics trade association (BREMA) lacks the resources or the inclination to coordinate research, but its work on standirds is acknowledged by firms to be important. In telecommunications the firms involved are so large. and so few in number. that they hardly need an external body for R \& D. but in any case have locked themselves into cost-plus contracting with British $\mathrm{T}$ clecom. which maintains its own extensive R \& D facilities.

At a less general livel. there is much to be explored in the interactions. strategic or otherwise. between firms and state agencies over support programmes and investment grants, as well as in pursuit of favourable tariff policics and the likc. In th is regard Williamson"s work on Markets and Hierarchies [1975] deserves extcnded trciltment.

Williamson"s focus is on the factors which govern the allocation of economic activities between firms and markets. which he analyses under the heading of 'transaction costs'. If the costs of procuring. say. a component in the market become too high. then the firm will bring that activity within its structurc by starting manufacture of the component itself. Initial sourcing of a component may bc untroublesome, with many bidders and market relations working properly. But on contract renewal the situation is transformed. with small numbers involved and a strong possibility of market failure. Williamson argues that with insufficient information (the bounded rationality problem) and opportunism (players acting with guile, e.g. lying about the performance of components) the costs of continuing a market relation can become large enough for the firm to replace market with hierarchy. Opportunism is a major problem where small numbers are involved (and th is is more frequent than most economists concede). and he points to the heavy costs involved in checking the truth or falsity of specific claims made in transactions.

The major area of application of such 'transactional analysis' is in providing an alternative to conventional explanations of changes in firm structure and the process of vertical integration. But also useful for our purposes would be the application of these ideas to transactions betwecn firms and the state. Here there is quite clearly a 'small numbers' problem of the kind argued by Williamson to contribute to market failure in the case of customer-supplier relationships. and ample scopc for opportunistic behaviour. Firms may exploit interventionist mechanisms to reduce their costs by maximising subsidies. and governments may find that the costs of checking firms' claims are prohibitive. This is relevant to any situation in which grants and incentives are offcred to industry on a discrctionary basis. It is encapsulated in the concept of 'additionality' which in theory is applied in Britain to the allocition to firms of selective finincial assistance.

A grant will only be given if it is put towards an investment which would not have been undertaken without the grant. Such counterfactual propositions are notoriously difficult to establish. even if all conceivible data are available. But when the relevant 
data are in the possession of the firm applying for the grant, the scope for opportunism is manifold. For major projects civil scrvants may employ outside consultants to advise whether the proposed invest ment was likely in the absence of subsidy, but for most decisions the statement by the firm that it would not have invested is regarded as sufficient to satisfy the additionality criterion. In at least one case reported to me, civil servants were attempting themselves to behave opportunistically by trying to maximise the grant payable to a major British-owned firm which they wanted to help. The board, reliant on a now apparently unfashionablc morality, refused to sign a statement to the effect that they had had no plans for the proposed investment, and so lost a considerable sum in aid.

Opportunisin is not, however, restricted to negotiations over grants. In pressing a claim for increased tariffs or support for bilateral export restraint agreements, firms may exaggerate the likely effects on employment and investment if the claim is not conceded. Protection may stave off the firm's need to undertake a costly reorganisation to respond to competitive pressures, but unless governments are able to make their own independent assessment of the strategic position of the major firms in the market, they will be unable to pursue policies with knowledge of their likely effects. Governments tend to employ simpler criteria, such as employment effects, which have an immediate and tangible political payoff. This is amply illustrated in McLean's study of The Inmos Saga. where there was a conflict between the company's strategic assessment of its preferred location for microchip manufacture, and the government's insistence on a location in an area of high unemployment. In Britain at least, it appears to be currently impossible for a firm dependent on public subsidy to trump the unemployment card.

The same issue arises in relation to inward investment in Britain, where the criteria employed (since November 1984) for regional assistance are no longer dependent on the simple test of whether the investment is physically located within a prescribed geographical area. In addition to location, additional einployment or the protection of those already employed inust be convincingly claimed. It is relatively easy to estimate the former, i.e. additional employınent arising from new investment, but more difficult to assess whether employment would be maintained in the absence of investment. Moreover the employment criterion is applied only in the relevant region, and government's assessment of employinent effects is not calculated to include the possible adverse effects on einployment elsewhere. The scope for opportunisin on the part of the inward investing firm, and on the part of its competitors when applying pressure to change government policy, is wide indeed. Our information suggests that in practice little has changed since November 1984, in that regional grants are still based on the routine administration of geographical criteria, whereas additional selective grants for projects 'deemed in the national interest' are decided on an ad hoc basis.

Our data on how far grants affect the strategic calculations of inward investors are only partial, but information about a few specific cases suggests that Japanese firms can behave opportunistically in negotiating assistance, by inaking claims about future plans for technology transfer which are impossible for civil servants to check at the time, and for which there exist no mechanisms to secure implementation. So far, Japanese investment in consumer electronics in Britain has not been 'footloose' in that firms have not uprooted at the end of their 'tax holiday' to take advantage of incentives elsewhere (in Britain or in Europe), and the parent companies appear to apply the same long-term horizon to their British subsidiaries that they do at home. Some at least of the firms seem to have been hard (and opportunistic) bargainers at first, but then have become established as 'good corporate citizens' afterwards.

The same kind of interaction between firms and governmental institutions can be observed at the European level over trade policy issues. The voluntary rest raint agreement negotiated at the behest of Philips and Grundig between the EEC and MITI arose after the firms, acting opportunistically, lodged an antidumping case against Japanese exporters to Europe. According to one source, Grundig deliberately secured an 'unwise' quotation for VCR supply from a Japanese firm in order to mount an anti-dumping suit. These cases are costly and difficult to prove, and it seems probable that this initiative was taken to push the EEC into action. In the event both the Commission and the firms miscalculated the effects of the restraint agreement, which seems to have operated almost entirely to the advantage of the 'restrained' exporters.

Thus it is important when considering the question of opportunism to allow for miscalculation and inadequate expertise. In earlier papers we have argued, consistent with Lindblom's (1977) thesis, that firms are in a stronger position than state agencies in bargaining because they can successfully claim a 'monopoly of legitimate expertise' [see also Bauer and Cohen 1985]. The tale of the EEC-MITI agreement should warn us, however, that firms are not necessarily more expert than governments in considering strategic inatters, and it should alert us to the possibility of capitalists as well as workers having a 'false consciousness' of their real interests. It is true, however, in defence of the Bauer and Cohen thesis, that government assessments depend on access to information controlled by the firms, and it is 
extremely costly to amass relevant information from other sources, even if it is possible. Interestingly, the European Commission has attempted recently to do this by employing consultants to evaluate the options open to firms in the European consumer electronics industry, but some of this information [see Booz-Allen and Hamilton 1985] is highly speculative in the absence of commercial information jealously guarded by the firms.

This article has suggested ways in which firms' strategies in relation both to the market and to governmental policies might be subjected to a political analysis. It remains somewhat impressionistic, partly because our own data are not yet complete, and partly because there is a dearth of comparable studies of the political role of firms. The task is, I submit, an urgent one, because firms' strategies have increasingly to be devised in the context of world markets, and international trade is mediated by the actions and policies of national governments and international bodies such as the EEC and GATT. To the extent that firms operating in international markets have developed close, even symbiotic, links with their national governments, the market has become an even more politicised set of relationships in a way which destroys any simple dichotomy between states and markets. National governments frequently represent the interests of their leading firms, so that firms as well as business interest associations can become "private interest governments' [Bauer and Cohen 1985]. This international dimension has become so important in the sectors we have studied that it deserves separate theoretical treatment.

\section{References}

Ansoff, H. I., 1968, Corporate Strategy. Penguin Books, Harmondsworth

Bain, J. S., 1956, Barriers to Nett Competition, Harvard University Press, Cámbridge (Mass.)

Bauer, M. and E. Cohen, 1985, Les Grandes Manoeuvres Industrielles, Belfond, Paris

Booz-Allen and Hamilton, 1985, EEC Consumer Electronics Industrial Policy: Final Report

Chandler, A. F., 1962, Strategy and Structure: Chapters in the History of an Industrial Enterprise, MIT Press, Cambridge (Mass.)

Channon, D. F., 1973, The Strategy and Structure of British Enterprises, Macmillan, London

Grant, W. P., W. Paterson and C. Whitston, 1985, 'Government-industry relations in the chemicals sector in West Germany', ESRC Conference Paper, December

Lindblom, C. E., 1977, Politics and Markets: the World's Political-Economic Sy'stems, Basic Books, New York

McLean, M., 1985, The Inmos Saga, Frances Pinter, London

March, J. G., 1962, 'The business firm as a political coalition', Jounal of Politics, November

Mason, E. S., 1957, Economic Concentration and the Monopoly Problem, Harvard University Press, Cambridge (Mass.)

Williamson, O. E., 1975, Markets and Hierarchies: Analysis and Antitrust Implications, The Free Press, New York 